\title{
EFFECT OF POTATO POWDER SUPPLEMENTATION AND SPICES ADDITION ON PHYSICAL AND SENSORY PROPERTIES OF COOKIES
}

\author{
Sreemoyee Chakraborty ${ }^{1}$, Saikat Mazumder $^{2}$, Soumitra Banerjee $^{3}$ \\ ${ }^{1}$ Department of Food Technology, Techno India, West Bengal, India \\ ${ }^{2}$ Department of Food Technology, Techno India University, West Bengal, India \\ ${ }^{3}$ Department of Food Technology, Techno India, West Bengal, India
}

\begin{abstract}
The objective of the study was to determine the acceptability of potato powder supplemented and spices added cookies based on their sensory and physical properties. Sensory evaluation was done based on hedonic scale. Potato powder supplementation was ranged from 10-50\% (wt. of flour/wt. of potato powder). Cardamom and clove were used as flavoring agent, which ranges from $0.5 \%$ to $1 \%$ (wt. of flour/wt. of spice). Increment in potato powder supplementation was lead to substantial decrement in physical properties and sensory evaluation $(P<0.05)$ irrespective of spices addition. 10-30\% replacement by potato powder was found to be acceptable. $10 \%$ replacement by potato powder and in combination with cardamom: clove ratio (1.5:0.5) was found to be the best in overall acceptability $(P<0.05)$. Moreover, the cookie samples prepared with formulations having potato powder and wheat flour ratio of 1:9 and 2:8 with the combination of cardamom and clove (1:1 and 1.5:0.5) had the same or higher sensory score than the conventional wheat flour cookies. ANOVA analysis showed that Variation in spices addition have a significant effect on flavour. Whereas, amount of replacement by potato powder has a significant effect on over all acceptability, taste, and colour $(P<0.05)$.
\end{abstract}

Keywords: cookies, potato powder supplementation, spices addition, sensory \& physical analysis, ANOVA analysis.

\section{INTRODUCTION}

Cookies are a widely consumed bakery product and there global consumption rate is only second to bread (according to Dun \& Bradstreet's Industry Reports, US, 2010). The U.S. Chamber of Commerce noted that cookie and cracker manufacturing was the fastest-growing segment of the bakery industry with an annual average increase of 2.3 per cent. This is because cookies come in a wide variety of types. The principal raw material used in cookie processing is wheat flour which is low in crude fibre content and mineral content. In recent years the interest in high fibre content in foods has greatly increased. High dietary fibre supplemented cookies have been prepared by replacing wheat flour with cereal by-products like corn bran, rice bran or barley husk [1] [2] [3].

Potato is a rich source of starch and regarded as the most important staple food in the world after rice. The potato contains vitamins and minerals, as well as an assortment of phytochemicals, such as carotenoids and natural phenols. Chlorogenic acid constitutes up to $90 \%$ of the potato tuber natural phenols. Others found in potatoes are 4Ocaffeoylquinic acid (crypto-chlorogenic acid), 5-Ocaffeoylquinic (neo-chlorogenic acid), 3,4-dicaffeoylquinic and 3,5-dicaffeoylquinic acids. The potato is best known for its carbohydrate content (approximately 26 grams in a medium potato). The predominant form of this carbohydrate is starch. A small but significant portion of this starch is resistant to digestion by enzymes in the stomach and small intestine, and so reaches the large intestine essentially intact. This resistant starch is considered to have similar physiological effects and health benefits as fiber. It provides bulk, offers protection against colon cancer, improves glucose tolerance and insulin sensitivity, lowers plasma cholesterol and triglyceride concentrations, increases satiety, and possibly even reduces fat storage [4]. Potato is also found to be a significant source of crude fibre. Potatoes also contain a variety of phytonutrients that have antioxidant activity. Among these important health-promoting compounds are carotenoids, flavonoids, and caffeic acid, as well as unique tuber storage proteins, such as patatin, which exhibit activity against free radicals [5].

Cookies enriched with crude fibre and minerals can be developed by partial supplementation of wheat flour with potato powder. The potato starch, fibre and minerals present in different levels in different percentage blends can affect the rheological properties of the cookie dough. The rheological characteristics of the dough are very important, as they influence the machinability of the dough as well as the quality of the finished product [6].

In the present study attempts have been made to investigate the maximum substitution of potato powder to wheat flour to improve the organoleptic and nutritional characteristics of cookies and use it for development of flavoured cookies. 
ANOVA has been widely used in sensory evaluation. It is regularly the first step for the differentiation of perceived sensory attributes among food samples. Noor Aziah and others have applied ANOVA for cookies incorporated with legume flour [7], Laura C. Okpala and Eric C. Okoli also have applied ANOVA for cookies containing germinated pigeon pea, fermented sorghum and cocoyam flour blends [8]. ANOVA has been extensively performed to evaluate the differentiation in the acceptability of sensory attributes when conducting consumer affective tests [9] [10] [11]. ANOVA has also been applied for the evaluation of the performance of trained panelists in descriptive sensory evaluation [9] [12] [13].

\section{MATERIAL \& METHODS}

\subsection{Preparation and Collection of Raw Materials}

\section{Preparation of Potato Powder}

Potatoes used in this study were of Chandramukhi variety freshly collected from local market of South Kolkata (cultivated in Tarakeswar, Hoogly district, West Bengal, India). The potatoes had initial moisture content of $82.34 \mathrm{gm}$ of moisture/100gm wet weight. The potato samples were washed with running tap water and distilled water respectively to make it free from dirt and soil and blotted with a tissue paper for removal of excess surface water. The potato samples were then peeled and cut into slices of equal thickness of $10 \pm 0.3 \mathrm{~mm}$ each. The sliced potato samples were blanched in hot water (Temperature- $90 \pm 20^{\circ} \mathrm{C}$ ) containing $2 \mathrm{gm} \mathrm{NaCl} / 100 \mathrm{gm}$ of water of sodium chloride $(\mathrm{NaCl})$ and $2 \mathrm{mg}$ of potassium meta-bisulphate/1000gm of water for 10 minutes and followed by preparation of mash in a mixer grinder. The potato mash was gelatinized in an autoclave at $10 \mathrm{psig}$ pressure for 15 minutes [14]. Then $2 \%$ wt/wt glycerol monostearate (GMS) was weighed and mixed with a refined vegetable oil and water in a ratio of $2: 1: 10$ respectively and heated in boiling water bath $\left(90-100^{\circ} \mathrm{C}\right)$ and stirred till GMS gets evenly dispersed to form slurry. The potato mash and water was added (in a ratio of 10:1 respectively) and stirred at $300 \mathrm{rpm}$ for 10 minutes in a magnetic stirrer (Eltek, Model - 2011) to form thick foam slurry. The foam mat drying experiment was carried out in a batch type tray drier (Suan Scientific Instruments \& Equipments). The drier was equipped with an electrical heater, blower (230rpm) and temperature indicators. It consisted of trays $(800 \times 400 \times 30 \mathrm{~mm})$ with perforations of diameter $7 \mathrm{~mm}$ and a temperature controller $\left(0-200^{\circ} \mathrm{C}\right)$. The tray drier was run intermittently in order to stabilize the desired temperature (i.e. $60^{\circ} \mathrm{C}$ ) inside the chamber. The homogeneous foamed potato slurry was poured over muslin cloth and spread to an equal thickness of $10 \mathrm{~mm}$. and kept over the drying trays. The trays were then placed on the tray stand in position for drying and the drying continued for $2 \mathrm{hrs} 15 \mathrm{mins}$ [15]. A crispy powder was obtained which was grounded to a fine powder and packed in LDPE zip pouches $(0.06 \mathrm{~mm}$ film thickness) and stored under ambient conditions.

\section{Preparation of Spices}

The spices are brought from local market of South Kolkata. Dried in tray drier at $40^{\circ} \mathrm{C}$ for 3-4 hours, powdered and packed in small glass bottles by covering the opening with aluminium foil followed by HDPE lids.

\section{Collection of other Ingredients}

Other ingredients like flour, sugar, butter, hydrogenated vegetable oils, whole eggs, baking powder and vanilla essence were procured from the local market of South Kolkata.

All the chemicals used were procured from MERCK.

\subsection{Preparation of Cookies}

The flour blends were prepared by mixing pre-determined portions of wheat flour and potato flour as required by the different formulations and kept separately. Coarsely grinded sugar and shortening agents (butter and Dalda) were throughly mixed in different proportions. Beaten whole egg was weighed to required portions and added accordingly. The flour blends were added to this mixture followed by baking powder and flavouring agents. After formation of the dough, it was cut and shaped into the formation of cookies. The baking pan was greased with butter-dalda mixture and the oven was pre-heated to $160^{\circ} \mathrm{C}$. The cookies were baked for $15-20 \mathrm{mins}$ till the golden brown crust appeared. The cookies were cooled to $30^{\circ} \mathrm{C}$ and kept at ambient temperature for further physical and sensory analysis.

\subsection{Development of Potato Supplemented}

\section{Flavoured Cookies}

At first different flour combinations of the wheat flour and potato powder were tried to obtain the best acceptable formulation. Sugar, shortening, whole egg (emulsifier), baking powder and essence was added to these formulations for preparation of cookies (Table 1). The best formulation was selected by sensorial quality characteristics like colour, flavour, taste, mouth feel, texture, spread, crispiness, grittiness (absence) and overall acceptability and evaluation of physical properties like spread, volume and density. Finally the proximate analysis of the standard and three most acceptable blends was done.

Three of the most acceptable formulations were further used for development of flavoured cookies using different combinations of selected spices like powdered cardamom and powdered clove. First the best acceptable amount spices (Table 1) that enhances the flavour and acceptability was selected by sensory analysis of un-supplemented wheat flour cookies $\left(\mathrm{C}_{9}-\mathrm{C}_{11}\right)$.

Then then the percentage of the two different spices was varied keeping the optimised amount constant and was used in the potato supplemented formulation (Table 1). The sensorial as well as physical quality characteristics were analysed. 
Table -1: Formulation of Flavoured Cookies

\begin{tabular}{|c|c|c|c|c|c|c|c|c|c|c|}
\hline \multirow[t]{2}{*}{$\begin{array}{l}\text { Sample } \\
\text { Code }\end{array}$} & \multirow{2}{*}{$\begin{array}{l}\text { Wheat } \\
\text { Flour } \\
\text { (gm) }\end{array}$} & \multirow{2}{*}{$\begin{array}{l}\text { Potato } \\
\text { Flour } \\
(\mathrm{gm})\end{array}$} & \multirow[t]{2}{*}{$\begin{array}{l}\text { Sugar } \\
(\mathrm{gm})\end{array}$} & \multicolumn{2}{|c|}{$\begin{array}{l}\text { Shortening } \\
(\mathrm{gm})\end{array}$} & \multirow{2}{*}{$\begin{array}{l}\text { Whole } \\
\text { Egg } \\
(\mathrm{gm})\end{array}$} & \multirow{2}{*}{$\begin{array}{l}\text { Baking } \\
\text { Powder } \\
(\mathrm{gm})\end{array}$} & \multirow{2}{*}{$\begin{array}{l}\text { Vanilla } \\
\text { Essence } \\
(\mathrm{ml})\end{array}$} & \multicolumn{2}{|l|}{ Spices (gm) } \\
\hline & & & & Butter & Dalda & & & & Cardamom & Clove \\
\hline $\mathrm{C}$ & 100 & - & 75 & 35 & 35 & 20 & 1 & 3 & - & - \\
\hline $\mathrm{C}_{1}$ & 90 & 10 & 75 & 35 & 35 & 20 & 1 & 3 & - & - \\
\hline $\mathrm{C}_{2}$ & 80 & 20 & 75 & 35 & 35 & 20 & 1 & 3 & - & - \\
\hline $\mathrm{C}_{3}$ & 70 & 30 & 75 & 35 & 35 & 20 & 1 & 3 & - & - \\
\hline $\mathrm{C}_{4}$ & 60 & 40 & 75 & 35 & 35 & 20 & 1 & 3 & - & - \\
\hline $\mathrm{C}_{5}$ & 50 & 50 & 75 & 35 & 35 & 20 & 1 & 3 & - & - \\
\hline $\mathrm{C}^{*}$ & 100 & - & 75 & 42 & 28 & 15 & 1 & 3 & - & - \\
\hline $\mathrm{C}_{6}$ & 90 & 10 & 75 & 42 & 28 & 15 & 1 & 3 & - & - \\
\hline $\mathrm{C}_{7}$ & 80 & 20 & 75 & 42 & 28 & 15 & 1 & 3 & - & - \\
\hline $\mathrm{C}_{8}$ & 70 & 30 & 75 & 42 & 28 & 15 & 1 & 3 & - & - \\
\hline $\mathrm{C}_{9}$ & 100 & - & 75 & 42 & 28 & 15 & 1 & 3 & 0.5 & 0.5 \\
\hline $\mathrm{C}_{10}$ & 100 & - & 75 & 42 & 28 & 15 & 1 & 3 & 0.75 & 0.75 \\
\hline $\mathrm{C}_{11}$ & 100 & - & 75 & 42 & 28 & 15 & 1 & 3 & 1 & 1 \\
\hline $\mathrm{C}_{12}$ & 90 & 10 & 75 & 42 & 28 & 15 & 1 & 3 & 0.5 & 1.5 \\
\hline $\mathrm{C}_{13}$ & 90 & 10 & 75 & 42 & 28 & 15 & 1 & 3 & 1 & 1 \\
\hline $\mathrm{C}_{14}$ & 90 & 10 & 75 & 42 & 28 & 15 & 1 & 3 & 1.5 & 0.5 \\
\hline $\mathrm{C}_{15}$ & 80 & 20 & 75 & 42 & 28 & 15 & 1 & 3 & 0.5 & 1.5 \\
\hline $\mathrm{C}_{16}$ & 80 & 20 & 75 & 42 & 28 & 15 & 1 & 3 & 1 & 1 \\
\hline $\mathrm{C}_{17}$ & 80 & 20 & 75 & 42 & 28 & 15 & 1 & 3 & 1.5 & 0.5 \\
\hline $\mathrm{C}_{18}$ & 70 & 30 & 75 & 42 & 28 & 15 & 1 & 3 & 0.5 & 1.5 \\
\hline $\mathrm{C}_{19}$ & 70 & 30 & 75 & 42 & 28 & 15 & 1 & 3 & 1 & 1 \\
\hline $\mathrm{C}_{20}$ & 70 & 30 & 75 & 42 & 28 & 15 & 1 & 3 & 1.5 & 0.5 \\
\hline
\end{tabular}

\subsection{Sensory Analysis of Cookies}

The sensory evaluation was carried out in order to get consumer response for overall acceptability of the potato flour supplemented cookies compared to the control cookies. Products were evaluated by a panel of 30 judges for different sensory attributes like colour, flavour, taste, mouth feel, texture, spread, crispiness, grittiness (absence) and overall acceptability. The 9 point hedonic scale developed by David Peryam and colleagues at the Quartermaster Food and Container Institute of the U.S. Armed Forces [16], was used for this purpose where 1 denotes Dislike Extremely and 9 denotes Like Extremely.

\subsection{Determination of Physical Characteristics of}

\section{Cookies}

Spread ratio: The spread ratio was determined by using the following formula:

Spread Ratio $=$ Diameter $(\mathrm{mm}) /$ Thickness $(\mathrm{mm})$

Thickness: The thickness was measured in $\mathrm{mm}$.

Diameter: The diameter was measured in $\mathrm{mm}$.

Volume: Volume of cookies is defined as the area of the biscuit multiplied by thickness.

$$
\text { Volume }=\mathrm{d}^{2} \pi \mathrm{T} / 4(\mathrm{cc})
$$

where, $\mathrm{T}=$ Average thickness of biscuit $(\mathrm{mm}) \& \mathrm{~d}=$ Diameter of biscuit (mm)

Density: After calculating volume, density was obtained by ratio of weight of volume:

Density = Mass of sample/Volume of sample $(\mathrm{gm} / \mathrm{cc})$

\subsection{Proximate Composition of the Developed}

\section{Cookies}

The proximate composition like moisture, ash, total protein, total fat, crude fibre, reducing sugar, total sugar and other carbohydrates of the most acceptable cookies was done based on AOAC protocol [17]. All experiments were done triplicate times.

\subsection{Localization Study}

In localization study contour plots were obtained by using Statistica (version 7) (Stat Soft, Inc., USA). The Contour plot describing combined effect between pair of variation in formulation-spread ratio on sensory rating of spread (Table 2), combined effect of volume (cc) and variation in formulation on sensory score of texture (Table 2), and combined effect of density $(\mathrm{gm} / \mathrm{cc})$ and variation in formulation on sensory score of crispness (Table 2) was studied.

\subsection{Analysis of Variance (ANOVA) - Main Effects ANOVA}

Analysis of variance (ANOVA) is a statistical technique to analyze variation in a response variable (continuous random variable) measured under conditions defined by discrete factors (classification variables, often with nominal levels). Frequently, we use ANOVA to test equality among several means by comparing variance among groups relative to variance within groups (random error). In this study Main Effects ANOVA was performed (using STATISTICA, 
Version-7.0, Inc- USA) to see whether potato powder induced cookies in combination with spices has any significant effect on sensory rating or not (Table 3). The Main Effects ANOVA also helps to see which independent parameter has more significant on sensory rating among the significant parameter. The significance was judged by comparison of $\mathrm{F}$ value for that particular independent component or effect with Standard $\mathrm{F}$ value at a particular significant level. Here significant level was decided at 0.05 i.e. $95 \%$ confidence limit.

\section{RESULT \& DISCUSSIONS}

\subsection{Standardization of Formulation for}

\section{Development of only Potato Powder Supplemented}

\section{Cookies}

\subsubsection{Effect of Potato Powder Supplementation on}

\section{Sensorial and Physical Properties}

The cookies were prepared with different flour combinations $\left(\mathrm{C}, \mathrm{C}_{1}, \mathrm{C}_{2}, \mathrm{C}_{3}, \mathrm{C}_{4}, \mathrm{C}_{5}\right.$; Table 1) were subjected to sensory analysis and the results are given in Table 2 . While samples
$\mathrm{C}, \mathrm{C}_{1}, \mathrm{C}_{2}$ and $\mathrm{C}_{3}$ showed favourable results, organoleptically $\mathrm{C}_{4}$ and $\mathrm{C}_{5}$ were not acceptable. This is due to less spread, hardness, lack of crispiness and slight salty taste. While the salty taste came from blanching of potato before drying and grinding to powder, the other less desirable characteristics can be attributed to the potato starch which affects the texture of cookies making it hard. Some observations were also made on precedence of the flavour of egg and vanaspati over the normal flavour of cookies. So changes were made to the formulation accordingly $\left(\mathrm{C}^{*}, \mathrm{C}_{6}, \mathrm{C}_{7}, \mathrm{C}_{8}\right.$; Table 1) and subjected to sensory analysis (Table 2) and the new formulation was found to be more acceptable.

Table -2: Effect of Flour Blends and Ingredients on Sensory Attributes and Physical Properties of Cookies

\begin{tabular}{|c|c|c|c|c|c|c|c|c|c|}
\hline \multicolumn{10}{|c|}{ Sensory Analysis of Potato Powder Supplemented and Standard Wheat Flour Cookies } \\
\hline $\begin{array}{l}\text { Sample } \\
\text { Code }\end{array}$ & Colour & Flavour & Taste & $\begin{array}{l}\text { Mouth } \\
\text { feel }\end{array}$ & Texture & Spread & Crispiness & $\begin{array}{l}\text { Grittiness } \\
\text { (Absence) }\end{array}$ & $\begin{array}{l}\text { Overall } \\
\text { Acceptability }\end{array}$ \\
\hline $\mathrm{C}$ & $\begin{array}{l}8.56 \\
0.617\end{array}$ & $\begin{array}{ll}8.52 & \pm \\
0.123 & \end{array}$ & $\begin{array}{l}8.86 \pm \\
0.248\end{array}$ & $\begin{array}{l}8.9 \pm \\
0.854\end{array}$ & $\begin{array}{l}8.88 \pm \\
0.412\end{array}$ & $\begin{array}{l}8.91 \pm \\
0.512\end{array}$ & $\begin{array}{ll}8.92 & \pm \\
0.475 & \end{array}$ & $\begin{array}{ll}8.79 & \pm \\
0.551 & \end{array}$ & $8.37 \pm 0.217$ \\
\hline $\mathrm{C}_{1}$ & $\begin{array}{l}8.66 \\
0.413\end{array}$ & $\begin{array}{ll}8.35 & \pm \\
0.548 & \end{array}$ & $\begin{array}{l}8.66 \pm \\
0.714\end{array}$ & $\begin{array}{l}8.73 \pm \\
0.236\end{array}$ & $\begin{array}{l}8.43 \pm \\
0.612\end{array}$ & $\begin{array}{l}8.98 \pm \\
0.841\end{array}$ & $\begin{array}{l}8.61 \\
0.194\end{array}$ & $\begin{array}{l}8.54 \\
0.714\end{array}$ & $8.12 \pm 0.514$ \\
\hline $\mathrm{C}_{2}$ & $\begin{array}{l}8.36 \\
0.761\end{array}$ & $\begin{array}{l}8.15 \\
0.237\end{array}$ & $\begin{array}{l}8.51 \\
0.285\end{array}$ & $\begin{array}{l}8.49 \pm \\
0.666\end{array}$ & $\begin{array}{l}8.14 \pm \\
0.718\end{array}$ & $\begin{array}{l}8.48 \pm \\
0.749\end{array}$ & $\begin{array}{l}8.48 \\
0.646\end{array}$ & $\begin{array}{l}8.37 \\
0.615\end{array}$ & $8.01 \pm 0.639$ \\
\hline $\mathrm{C}_{3}$ & $\begin{array}{l}8.28 \\
0.349\end{array}$ & $\begin{array}{l}7.86 \\
0.549\end{array}$ & $\begin{array}{l}7.93 \pm \\
0.419\end{array}$ & $\begin{array}{l}7.87 \pm \\
0.615\end{array}$ & $\begin{array}{l}7.77 \pm \\
0.654\end{array}$ & $\begin{array}{l}7.53 \pm \\
0.218\end{array}$ & $\begin{array}{l}7.44 \\
0.343\end{array}$ & $\begin{array}{l}7.41 \\
0.915\end{array}$ & $7.78 \pm 0.735$ \\
\hline $\mathrm{C}_{4}$ & $\begin{array}{l}8.17 \\
0.716\end{array}$ & $\begin{array}{l}7.59 \\
0.712\end{array}$ & $\begin{array}{l}7.47 \pm \\
0.796\end{array}$ & $\begin{array}{l}7.01 \pm \\
0.645\end{array}$ & $\begin{array}{l}6.61 \pm \\
0.715\end{array}$ & $\begin{array}{l}6.21 \pm \\
0.743\end{array}$ & $\begin{array}{l}6.14 \\
0.447\end{array}$ & $\begin{array}{l}6.29 \\
0.255\end{array}$ & $6.44 \pm 0.846$ \\
\hline $\mathrm{C}_{5}$ & $\begin{array}{l}8.02 \\
0.444\end{array}$ & $\begin{array}{l}7.31 \\
0.814\end{array}$ & $\begin{array}{l}7.22 \pm \\
0.218\end{array}$ & $\begin{array}{l}6.66 \pm \\
0.121\end{array}$ & $\begin{array}{l}6.03 \pm \\
0.639\end{array}$ & $\begin{array}{l}6 \quad \pm \\
0.444\end{array}$ & $\begin{array}{l}5.23 \\
0.234\end{array}$ & $\begin{array}{ll}5.06 & \pm \\
0.148 & \end{array}$ & $5.67 \pm 0.851$ \\
\hline $\mathrm{C}^{*}$ & $\begin{array}{l}8.88 \\
0.376\end{array}$ & $\begin{array}{l}8.92 \\
0.377 \\
\end{array}$ & $\begin{array}{l}8.9 \pm \\
0.555\end{array}$ & $\begin{array}{l}8.97 \pm \\
0.412\end{array}$ & $\begin{array}{ll}8.88 & \pm \\
0.173 & \end{array}$ & $\begin{array}{l}8.93 \pm \\
0.881\end{array}$ & $\begin{array}{l}8.96 \\
0.177\end{array}$ & $8.9 \pm 0.212$ & $8.51 \pm 0.224$ \\
\hline $\mathrm{C}_{6}$ & $\begin{array}{l}8.82 \\
0.815\end{array}$ & $\begin{array}{l}8.81 \\
0.141\end{array}$ & $\begin{array}{l}8.76 \pm \\
0.624\end{array}$ & $\begin{array}{l}8 . \quad \pm \\
0.854\end{array}$ & $\begin{array}{l}8.51 \pm \\
0.023\end{array}$ & $\begin{array}{l}8.96 \pm \\
0.622\end{array}$ & $\begin{array}{l}8.88 \\
0.222\end{array}$ & $\begin{array}{l}8.86 \\
0.614\end{array}$ & $8.34 \pm 0.137$ \\
\hline $\mathrm{C}_{7}$ & $\begin{array}{ll}8.71 & \pm \\
0.183 & \end{array}$ & $\begin{array}{ll}8.76 & \pm \\
0.357 & \end{array}$ & $\begin{array}{l}8.58 \quad \pm \\
0.251\end{array}$ & $\begin{array}{l}8.417 \\
0.41\end{array}$ & $\begin{array}{l}8.32 \pm \\
0.712\end{array}$ & $\begin{array}{l}8.54 \pm \\
0.727\end{array}$ & $\begin{array}{ll}8.51 & \pm \\
0.854 & \end{array}$ & $\begin{array}{ll}8.53 & \pm \\
0.274 & \end{array}$ & $8.15 \pm 0.358$ \\
\hline $\mathrm{C}_{8}$ & $\begin{array}{ll}8.32 & \pm \\
0.142 & \end{array}$ & $\begin{array}{ll}8.61 & \pm \\
0.324 & \end{array}$ & $\begin{array}{l}7.91 \quad \pm \\
0.222\end{array}$ & $\begin{array}{l}7.88 \pm \\
0.617\end{array}$ & $\begin{array}{l}7.81 \pm \\
0.674\end{array}$ & $\begin{array}{l}7.78 \pm \\
0.219\end{array}$ & $\begin{array}{ll}7.66 & \pm \\
0.519 & \end{array}$ & $8 \pm 0.218$ & $7.93 \pm 0.111$ \\
\hline \multicolumn{10}{|c|}{ Physical Properties of Potato Powder Substituted Cookies \& Standard Wheat Flour Cookies } \\
\hline $\begin{array}{l}\text { Sample } \\
\text { Code }\end{array}$ & $\begin{array}{l}\text { Thickness } \\
(\mathrm{mm})\end{array}$ & $\begin{array}{l}\text { Diameter } \\
(\mathrm{mm})\end{array}$ & $\begin{array}{l}\text { Weight } \\
(\mathrm{gm})\end{array}$ & \multicolumn{2}{|c|}{ Spread Ratio } & \multicolumn{2}{|c|}{ Volume (cc) } & \multicolumn{2}{|c|}{ Density $(\mathrm{gm} / \mathrm{cc})$} \\
\hline $\mathrm{C}$ & $19 \pm 1.126$ & $\begin{array}{ll}48 & \pm \\
1.733 & \end{array}$ & $\begin{array}{l}20.56 \pm \\
0.154\end{array}$ & \multicolumn{2}{|c|}{$2.52 \pm 0.811$} & \multicolumn{2}{|c|}{$34.381 \pm 0.315$} & \multicolumn{2}{|l|}{$0.581 \pm 0.711$} \\
\hline $\mathrm{C}_{1}$ & $19 \pm 1.311$ & $\begin{array}{l}48 \\
1.914\end{array}$ & $\begin{array}{l}20.31 \pm \\
0.457\end{array}$ & \multicolumn{2}{|c|}{$2.52 \pm 0.724$} & \multicolumn{2}{|c|}{$34.381 \pm 0.211$} & \multicolumn{2}{|l|}{$0.581 \pm 0.125$} \\
\hline $\mathrm{C}_{2}$ & $19 \pm 1.177$ & $\begin{array}{l}45 \\
1.842\end{array}$ & $\begin{array}{l}20.07 \pm \\
0.272\end{array}$ & \multicolumn{2}{|c|}{$2.36 \pm 0.941$} & \multicolumn{2}{|c|}{$30.218 \pm 0.248$} & \multicolumn{2}{|l|}{$0.662 \pm 0.956$} \\
\hline $\mathrm{C}_{3}$ & $19 \pm 1.111$ & $\begin{array}{ll}41 & \pm \\
1.732 & \\
\end{array}$ & $\begin{array}{l}20.62 \pm \\
0.317\end{array}$ & \multicolumn{2}{|c|}{$2.15 \pm 0.264$} & \multicolumn{2}{|c|}{$25.084 \pm 0.824$} & \multicolumn{2}{|l|}{$0.797 \pm 0.825$} \\
\hline
\end{tabular}




\begin{tabular}{|c|c|c|c|c|c|c|}
\hline $\mathrm{C}_{4}$ & $19 \pm 1.256$ & $\begin{array}{ll}35 & \pm \\
1.821 & \end{array}$ & $\begin{array}{l}20.33 \pm \\
0.442\end{array}$ & $1.84 \pm 0.722$ & $18.280 \pm 0.171$ & $1.094 \pm 0.458$ \\
\hline $\mathrm{C}_{5}$ & $19 \pm 1.198$ & $\begin{array}{ll}30 & \pm \\
1.911 & \end{array}$ & $\begin{array}{l}20.51 \pm \\
0.817\end{array}$ & $1.57 \pm 0.944$ & $13.430 \pm 0.215$ & $1.489 \pm 0.213$ \\
\hline $\mathrm{C}^{*}$ & $19 \pm 1.241$ & $\begin{array}{ll}50 & \pm \\
1.814 & \end{array}$ & $\begin{array}{l}20.19 \pm \\
0.512\end{array}$ & $2.63 \pm 0.516$ & $37.306 \pm 0.261$ & $0.536 \pm 0.117$ \\
\hline $\mathrm{C}_{6}$ & $19 \pm 1.855$ & $\begin{array}{ll}50 & \pm \\
1.712 & \end{array}$ & $\begin{array}{l}20.82 \pm \\
0.336\end{array}$ & $2.63 \pm 0.218$ & $37.306 \pm 0.518$ & $0.536 \pm 0.221$ \\
\hline $\mathrm{C}_{7}$ & $19 \pm 1.954$ & $\begin{array}{ll}47 & \pm \\
1.721 & \end{array}$ & $\begin{array}{l}20.37 \pm \\
0.348\end{array}$ & $2.47 \pm 0.897$ & $32.963 \pm 0.742$ & $0.606 \pm 0.242$ \\
\hline $\mathrm{C}_{8}$ & $19 \pm 1.742$ & $\begin{array}{ll}43 & \pm \\
1.915 & \end{array}$ & $\begin{array}{l}20.41 \pm \\
0.547\end{array}$ & $2.26 \pm 0.415$ & $27.591 \pm 0.911$ & $0.725 \pm 0.714$ \\
\hline
\end{tabular}

Physical properties like spread-ratio, volume and density are indicators of the characteristics of cookies and can be used as a tool to justify the organoleptic score on spread, texture and crispiness. While proper rise in volume can provide a superior texture, an increase in density can lead to compactness, hardness and loss of crispiness.

Table 2 shows a decrease in volume and an increase in density with increase in potato powder percentage. The volume and density of the first three blends of wheat flour: potato powder $(90: 10,80: 20,70: 30)$ is comparable with the control sample but after that increase in potato powder percentage lead to increase in density and decrease in volume. These results (Table 2) are backed up by the sensory score (Table 2) which shows a drop in acceptability of cookies after $30 \%$ potato powder supplement. These results can be backed up by studies made by El Sahy [18].

\subsubsection{Proximate Analysis of Wheat Flour Cookies} and Potato Powdered Supplemented Cookies

The analysis of nutritional constituents of the most acceptable potato powder supplemented cookie samples $\left(\mathrm{C}_{6}\right.$, $\mathrm{C}_{7}, \mathrm{C}_{8}$ ) and the standard wheat flour cookies $\mathrm{C}^{*}$ is given in Table 3. The results show that the cookies supplemented with potato powder are rich in crude fibres and minerals.

Table -3: Nutritional Composition of Cookies with and without Partial Supplementation of Potato Powder

\begin{tabular}{|l|l|l|l|l|}
\hline Composition & Amount in $\mathrm{C}^{*}(\%)$ & Amount in $\mathrm{C}_{6}(\%)$ & Amount in $\mathrm{C}_{7}(\%)$ & Amount in $\mathrm{C}_{8}(\%)$ \\
\hline Moisture & $2.36 \pm 0.262$ & $2.99 \pm 0.137$ & $3.36 \pm 0.164$ & $3.96 \pm 0.851$ \\
\hline Ash & $0.871 \pm 0.123$ & $1.067 \pm 0.411$ & $1.115 \pm 0.322$ & $1.406 \pm 0.189$ \\
\hline Fat & $31.44 \pm 0.371$ & $29.93 \pm 0.422$ & $30.63 \pm 0.312$ & $30.85 \pm 0.528$ \\
\hline Protein & $3.465 \pm 0.121$ & $3.898 \pm 0.112$ & $3.632 \pm 0.137$ & $3.711 \pm 0.198$ \\
\hline Crude Fibre & $0.29 \pm 0.013$ & $0.77 \pm 0.0 .23$ & $1.02 \pm 0.031$ & $1.29 \pm 0.024$ \\
\hline Reducing Sugar & $3.09 \pm 0.167$ & $3.36 \pm 0.185$ & $3.62 \pm 0.191$ & $3.09 \pm 0.213$ \\
\hline Total Sugar & $22.17 \pm 0.521$ & $22.17 \pm 0.313$ & $22.68 \pm 0.179$ & $22.43 \pm 0.184$ \\
\hline Other Carbohydrates & $36.05 \pm 0.314$ & $35.311 \pm 0.815$ & $33.08 \pm 0.843$ & $33.61 \pm 0.263$ \\
\hline
\end{tabular}

\subsubsection{Localization Study}

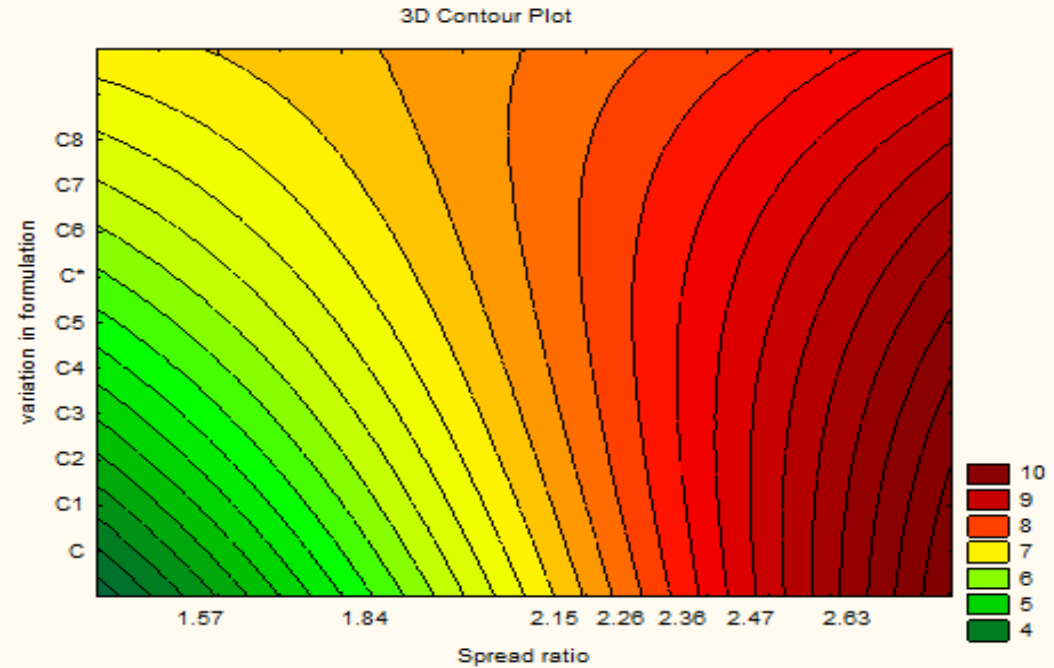

Fig -1: Contour plot for combined effect of Spread ratio and variation in formulation on sensory score of spread 
Fig 1 shows that sensory rating of spread (Table 2) is as a combined effect of variation in formulation i.e. different recipe of cookies (Table 2) and spread ratio (Table 2). The figure indicates that the sensory rating for spread of different cookies increases with the increment in spread ratio.

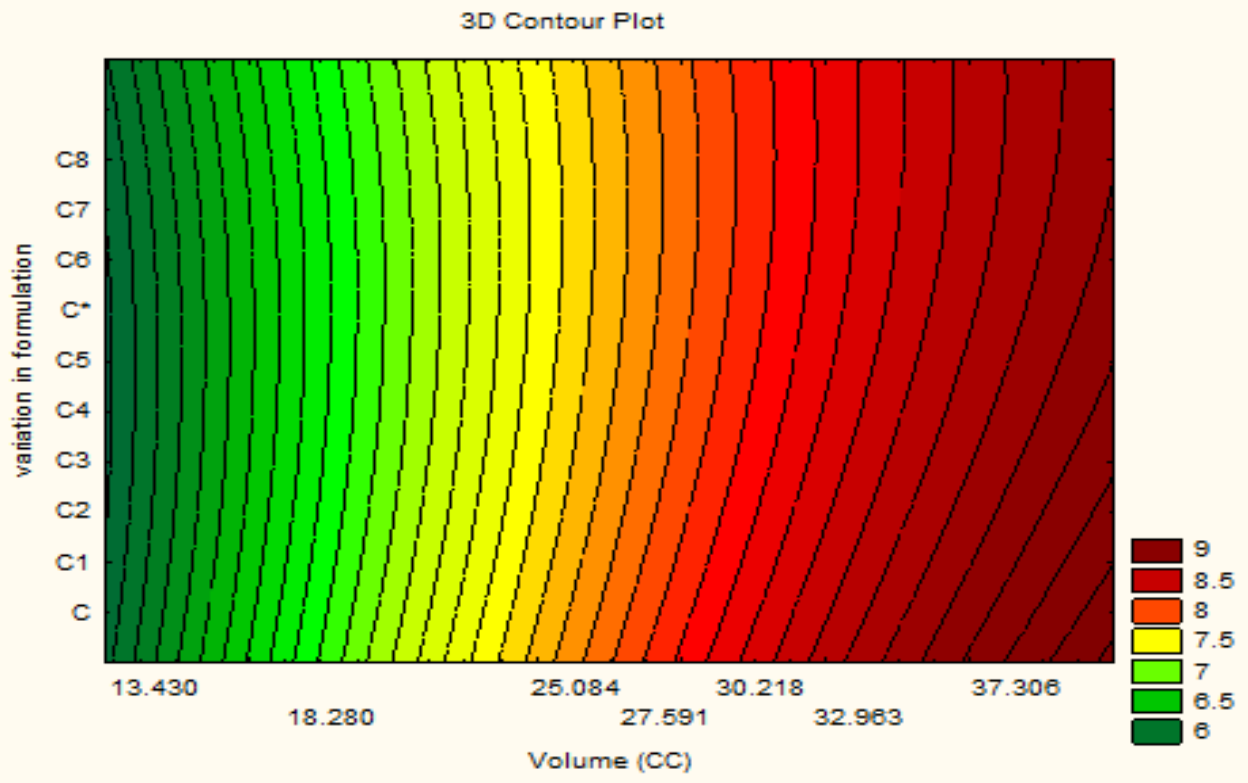

Fig -2: Contour plot for combined effect of volume and variation in formulation on sensory score of texture

Fig 2 shows that sensory rating of texture (Table 2) is as a combined effect of variation in formulation i.e. different recipe of cookies (Table 2) and volume of different cookies (Table 2). The figure indicates that the sensory rating for texture of different cookies increases with the increment in volume. The results also indicate that volume of cookies also affect the texture of cookies very positively i.e. more the volume of cookies more the sensory appeal of those cookies.

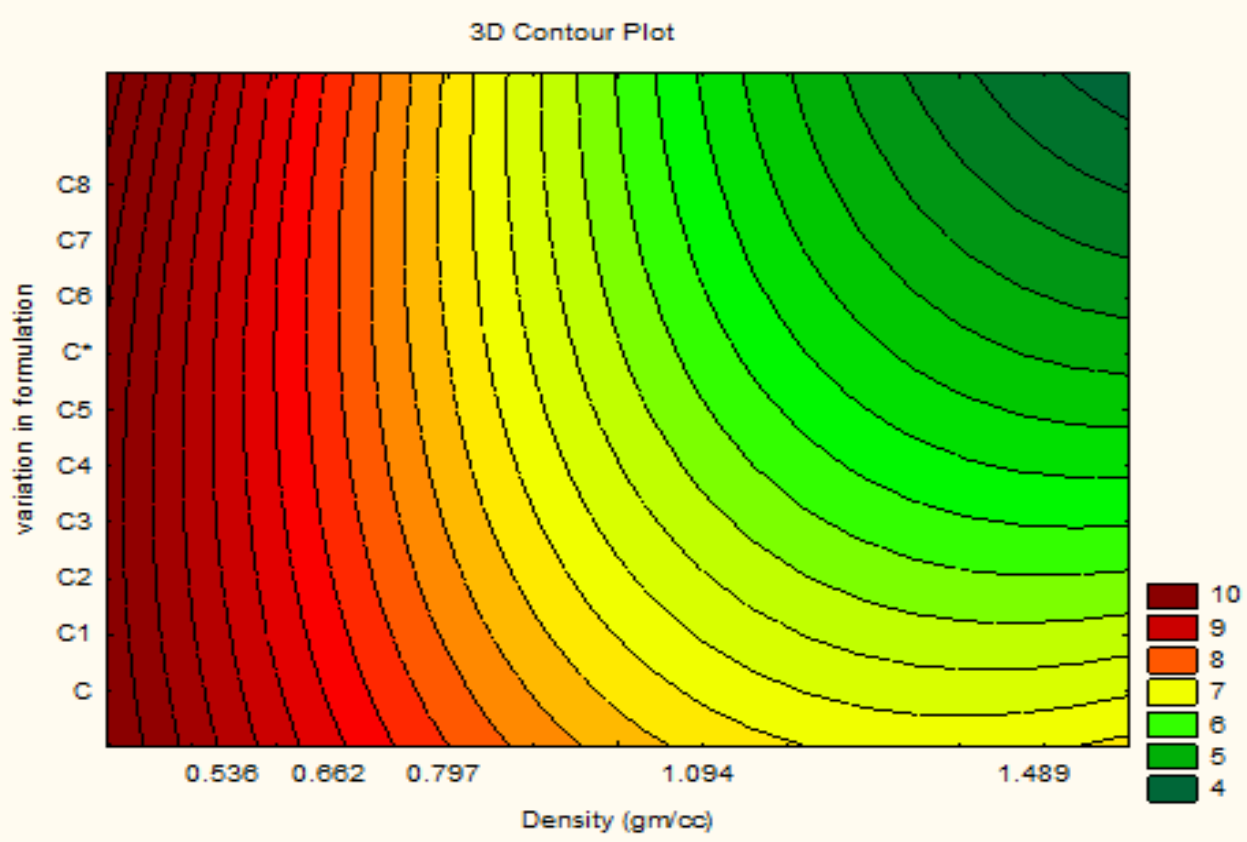

Fig -3: Contour plot for combined effect of density and variation in formulation on sensory score of crispness

Fig 3 shows that sensory rating of crispiness (Table 2) is as a combined effect of variation in formulation i.e. different recipe of cookies (Table 2) and density of different cookies (Table 2). The figure indicates that the sensory rating for texture of different cookies decreases with the increment in density. The results also indicate that density of cookies also affect the crispiness of cookies very negatively i.e. more the density of cookies, less the sensory appeal of those cookies. 
3.2 Standardization of Formulation for

Development of Potato Powder Supplemented Flavoured Cookies

\subsubsection{Effect of Species Addition and Potato Powder}

\section{Supplementation on Sensorial and Physical}

\section{Properties}

$1 \%, 1.5 \%$ and $2 \%$ of cardamom and clove mixture containing each constituent at a ratio of 1:1 was added to

$100 \mathrm{gm}$ wheat flour during development of cookies. The spice percentage was optimised based on the sensory analysis of flavoured cookies (Table 4). The most acceptable variety is obtained to be $\mathrm{C}_{11}$.

Table 4: Effect of Spices on Sensory Attributes and Physical Properties of Cookies

\begin{tabular}{|c|c|c|c|c|c|c|c|c|c|}
\hline \multicolumn{10}{|c|}{ Sensory Analysis of Wheat Flour and Potato Supplemented Flavoured Cookies } \\
\hline $\begin{array}{l}\text { Sample } \\
\text { Code }\end{array}$ & Colour & Flavour & Taste & $\begin{array}{l}\text { Mouth } \\
\text { feel }\end{array}$ & Texture & Spread & Crispiness & $\begin{array}{l}\text { Grittiness } \\
\text { (Absence) }\end{array}$ & $\begin{array}{l}\text { Overall } \\
\text { Acceptability }\end{array}$ \\
\hline $\mathrm{C}_{9}$ & $\begin{array}{l}8.82 \pm \\
0.651\end{array}$ & $\begin{array}{ll}8.84 & \pm \\
0.291 & \end{array}$ & $\begin{array}{l}8.86 \pm \\
0.321\end{array}$ & $\begin{array}{l}8.85 \pm \\
0.313\end{array}$ & $\begin{array}{ll}8.77 & \pm \\
0.894 & \end{array}$ & $\begin{array}{l}8.85 \pm \\
0.325\end{array}$ & $\begin{array}{l}8.86 \\
0.449\end{array}$ & $8.6 \pm 0.365$ & $8.28 \pm 0.191$ \\
\hline $\mathrm{C}_{10}$ & $\begin{array}{l}8.84 \quad \pm \\
0.321\end{array}$ & $\begin{array}{ll}8.12 & \pm \\
0.831 & \\
\end{array}$ & $\begin{array}{l}8.19 \pm \\
0.298\end{array}$ & $\begin{array}{l}8.82 \pm \\
0.815\end{array}$ & $\begin{array}{ll}8.64 & \pm \\
0.834 & \end{array}$ & $\begin{array}{l}8.81 \pm \\
0.256\end{array}$ & $\begin{array}{l}8.91 \\
0.542\end{array}$ & $8.75 \pm 0.945$ & $8.44 \pm 0.655$ \\
\hline $\mathrm{C}_{11}$ & $\begin{array}{l}8.86 \pm \\
0.781\end{array}$ & $\begin{array}{l}8.39 \pm \\
0.666\end{array}$ & $\begin{array}{l}8.64 \pm \\
0.452\end{array}$ & $\begin{array}{l}8.87 \pm \\
0.226\end{array}$ & $\begin{array}{ll}8.76 & \pm \\
0.172 & \end{array}$ & $\begin{array}{l}8.73 \pm \\
0.881\end{array}$ & $\begin{array}{l}8.72 \\
0.133\end{array}$ & $8.83 \pm 0.512$ & $8.63 \pm 0.241$ \\
\hline $\mathrm{C}_{12}$ & $\begin{array}{l}8.79 \pm \\
0.512\end{array}$ & $\begin{array}{ll}8.37 & \pm \\
0.912 & \end{array}$ & $\begin{array}{l}8.34 \pm \\
0.951\end{array}$ & $\begin{array}{l}8.84 \pm \\
0.915\end{array}$ & $\begin{array}{ll}8.83 & \pm \\
0.654 & \end{array}$ & $\begin{array}{l}8.79 \pm \\
0.948\end{array}$ & $\begin{array}{l}8.74 \\
0.214\end{array}$ & $8.75 \pm 0.212$ & $8.39 \pm 0.721$ \\
\hline $\mathrm{C}_{13}$ & $\begin{array}{l}8.69 \pm \\
0.543\end{array}$ & $\begin{array}{ll}8.67 & \pm \\
0.524 & \end{array}$ & $\begin{array}{l}8.33 \pm \\
0.271\end{array}$ & $\begin{array}{l}8.73 \pm \\
0.441\end{array}$ & $\begin{array}{ll}8.69 & \pm \\
0.415 & \end{array}$ & $\begin{array}{l}8.56 \pm \\
0.944\end{array}$ & $\begin{array}{l}8.72 \\
0.743\end{array}$ & $8.53 \pm 0.957$ & $8.77 \pm 0.584$ \\
\hline $\mathrm{C}_{14}$ & $\begin{array}{l}8.8 \pm \\
0.628\end{array}$ & $\begin{array}{ll}8.86 & \pm \\
0.881 & \end{array}$ & $\begin{array}{l}8.71 \pm \\
0.711\end{array}$ & $\begin{array}{l}8.84 \pm \\
0.322\end{array}$ & $\begin{array}{ll}8.73 & \pm \\
0.521 & \end{array}$ & $\begin{array}{l}8.88 \pm \\
0.212\end{array}$ & $\begin{array}{lll}8.91 & \pm & 0 \\
.642 & & \end{array}$ & $8.79 \pm 0.987$ & $8.8 \pm 0.217$ \\
\hline $\mathrm{C}_{15}$ & $\begin{array}{l}8.81 \pm \\
0.832\end{array}$ & $\begin{array}{l}7.68 \quad \pm \\
0.542\end{array}$ & $\begin{array}{l}8.29 \pm \\
0.548\end{array}$ & $\begin{array}{l}7.65 \pm \\
0.495\end{array}$ & $\begin{array}{l}8.78 \quad \pm \\
0.959\end{array}$ & $\begin{array}{l}8.7 \pm \\
0.568\end{array}$ & $\begin{array}{ll}8.83 & \pm \\
0.951 & \end{array}$ & $8.11 \pm 0.336$ & $7.98 \pm 0.851$ \\
\hline $\mathrm{C}_{16}$ & $\begin{array}{l}8.84 \pm \\
0.472\end{array}$ & $\begin{array}{ll}8.33 & \pm \\
0.424 & \\
\end{array}$ & $\begin{array}{l}8.41 \pm \\
0.624\end{array}$ & $\begin{array}{l}8.83 \pm \\
0.412\end{array}$ & $\begin{array}{ll}8.83 & \pm \\
0.241 & \\
\end{array}$ & $\begin{array}{l}8.87 \pm \\
0.412\end{array}$ & $\begin{array}{l}8.81 \\
0.847\end{array}$ & $8.47 \pm 0.945$ & $8.71 \pm 0.312$ \\
\hline $\mathrm{C}_{17}$ & $\begin{array}{l}8.86 \pm \\
0.215\end{array}$ & $\begin{array}{ll}8.97 & \pm \\
0.341 & \end{array}$ & $\begin{array}{l}8.95 \pm \\
0.623\end{array}$ & $\begin{array}{l}8.97 \pm \\
0.111\end{array}$ & $\begin{array}{ll}8.81 & \pm \\
0.674 & \end{array}$ & $\begin{array}{l}8.93 \pm \\
0.492\end{array}$ & $\begin{array}{l}8.97 \\
0.77\end{array}$ & $8.95 \pm 0.333$ & $8.79 \pm 0.309$ \\
\hline $\mathrm{C}_{18}$ & $\begin{array}{l}8.05 \pm \\
0.194\end{array}$ & $\begin{array}{ll}7.42 & \pm \\
0.427 & \\
\end{array}$ & $\begin{array}{l}7.32 \pm \\
0.662\end{array}$ & $\begin{array}{l}7.74 \quad \pm \\
0.221\end{array}$ & $\begin{array}{ll}7.01 & \pm \\
0.619 & \\
\end{array}$ & $\begin{array}{l}7 \\
0.173\end{array}$ & $\begin{array}{l}7.04 \\
0.638\end{array}$ & $7.97 \pm 0.086$ & $7.07 \pm 0.013$ \\
\hline $\mathrm{C}_{19}$ & $\begin{array}{l}8.11 \pm \\
0.433\end{array}$ & $\begin{array}{ll}8.08 & \pm \\
0.107 & \end{array}$ & $\begin{array}{l}7.48 \pm \\
0.323\end{array}$ & $\begin{array}{l}8.13 \pm \\
0.372\end{array}$ & $\begin{array}{ll}7.33 & \pm \\
0.242 & \end{array}$ & $\begin{array}{l}7.28 \pm \\
0.241\end{array}$ & $\begin{array}{l}7.53 \\
0.126\end{array}$ & $8.21 \pm 0.356$ & $7.53 \pm 0.117$ \\
\hline $\mathrm{C}_{20}$ & $\begin{array}{ll}8.31 & \pm \\
0.573 & \\
\end{array}$ & $\begin{array}{ll}8.54 & \pm \\
0.177 & \\
\end{array}$ & $\begin{array}{l}7.81 \pm \\
0.121 .\end{array}$ & $\begin{array}{l}8.55 \pm \\
0.625\end{array}$ & $\begin{array}{ll}7.77 & \pm \\
0.258 & \\
\end{array}$ & $\begin{array}{l}7.64 \pm \\
0.317\end{array}$ & $\begin{array}{l}7.99 \\
0.487 \\
\end{array}$ & $8.68 \pm 0.324$ & $7.86 \pm 0.856$ \\
\hline \multicolumn{10}{|c|}{ Physical Properties of Potato Powder Supplemented Flavoured Cookies } \\
\hline $\begin{array}{l}\text { Sample } \\
\text { Code }\end{array}$ & \multicolumn{2}{|c|}{ Thickness (mm) } & \multicolumn{2}{|c|}{ Diameter $(\mathrm{mm})$} & \multicolumn{2}{|c|}{ Weight $(\mathrm{gm})$} & $\begin{array}{l}\text { Spread } \\
\text { Ratio }\end{array}$ & Volume (cc) & $\begin{array}{l}\text { Density }(\mathrm{gm} / \\
\mathrm{cc})\end{array}$ \\
\hline $\mathrm{C}_{12}$ & \multicolumn{2}{|c|}{$19 \pm 1.254$} & \multicolumn{2}{|c|}{$50 \pm 1.428$} & \multicolumn{2}{|c|}{$20.23 \pm 0.154$} & $\begin{array}{l}2.63 \\
0.101\end{array}$ & $\begin{array}{l}37.306 \\
0.371\end{array}$ & $0.542 \pm 0.651$ \\
\hline $\mathrm{C}_{13}$ & \multicolumn{2}{|l|}{$19 \pm 1.169$} & \multicolumn{2}{|c|}{$50 \pm 1.414$} & \multicolumn{2}{|c|}{$20.77 \pm 0.457$} & $\begin{array}{l}2.63 \\
0.744\end{array}$ & $\begin{array}{l}37.306 \\
0.562\end{array}$ & $0.556 \pm 0.786$ \\
\hline $\mathrm{C}_{14}$ & \multicolumn{2}{|c|}{$19 \pm 1.797$} & \multicolumn{2}{|c|}{$51 \pm 1.238$} & \multicolumn{2}{|c|}{$20.34 \pm 0.272$} & $\begin{array}{l}2.68 \\
0.888\end{array}$ & $\begin{array}{l}38.813 \\
0.911\end{array}$ & $0.524 \pm 0.297$ \\
\hline $\mathrm{C}_{15}$ & \multicolumn{2}{|c|}{$19 \pm 1.232$} & \multicolumn{2}{|c|}{$47 \pm 1.165$} & \multicolumn{2}{|c|}{$20.92 \pm 0.317$} & $\begin{array}{l}2.47 \\
0.614 \\
\end{array}$ & $\begin{array}{l}32.964 \\
0.101 \\
\end{array}$ & $0.634 \pm 0.567$ \\
\hline $\mathrm{C}_{16}$ & \multicolumn{2}{|c|}{$19 \pm 1.849$} & \multicolumn{2}{|c|}{$48 \pm 1.432$} & $20.48 \pm 0$ & & $\begin{array}{l}2.52 \\
0.241\end{array}$ & $\begin{array}{l}34.381 \\
0.624\end{array}$ & $0.596 \pm 0.253$ \\
\hline $\mathrm{C}_{17}$ & $19 \pm 1.37$ & & $48 \pm 1.33$ & & $20.11 \pm 0$ & & $\begin{array}{l}2.52 \\
0.717 \\
\end{array}$ & $\begin{array}{l}34.381 \\
0.444\end{array}$ & $0.585 \pm 0.233$ \\
\hline $\mathrm{C}_{18}$ & $19 \pm 1.92$ & & $43 \pm 1.01$ & & $20.61 \pm 0$. & & $\begin{array}{l}2.26 \\
0.111\end{array}$ & $\begin{array}{l}27.592 \\
0.327\end{array}$ & $0.747 \pm 0.181$ \\
\hline
\end{tabular}




\begin{tabular}{|l|l|l|l|lr|lr|l|}
\hline $\mathrm{C}_{19}$ & $19 \pm 1.184$ & $41 \pm 1.266$ & $20.93 \pm 0.336$ & 2.16 & \pm & 25.084 & \pm & $0.834 \pm 0.374$ \\
& & & & 0.431 & 0.913 & \\
\hline $\mathrm{C}_{20}$ & $19 \pm 1.256$ & $43 \pm 1.732$ & $20.88 \pm 0.348$ & 2.26 & \pm & 27.591 & \pm & $0.756 \pm 0.649$ \\
& & & & 0.106 & 0.091 & & \\
\hline
\end{tabular}

Formulations of $\mathrm{C}_{6}, \mathrm{C}_{7}$ and $\mathrm{C}_{8}$ were selected for addition of different quantitative combinations of cardamom and clove powder with the purpose of flavour enrichment (Table 1). For each of the three flour combinations the cardamom to clove ratio that was most acceptable was 1.5:0.5 $\left(\mathrm{C}_{14}, \mathrm{C}_{17}\right.$, and $\mathrm{C}_{20}$ ). From Table 4 it is seen that $\mathrm{C}_{14}$ and $\mathrm{C}_{17}$ are the two most acceptable combinations and the acceptability of $\mathrm{C}_{13}$, $\mathrm{C}_{14}, \mathrm{C}_{16}$, and $\mathrm{C}_{17}$ was found to be more than that of the standard $\mathrm{C}^{*}$.

The physical properties of flavoured cookies are shown in Table 4. The spread ratio is comparable to the standard while a slight decrease is noted in $\mathrm{C}_{18}, \mathrm{C}_{19}$ and $\mathrm{C}_{20}$. The spread ratio, volume and density of cookies consisting of wheat flour: potato powder blends of 90:10 and 80:20 as well as the cardamom: clove combinations of $1: 1$ and 1.5:0.5 is observed to be comparable to the control C.

\subsubsection{Main Effects ANOVA}

Main effects ANOVA was performed for the cookies developed with different combination of potato powder with different combination of potato for different attributes like overall acceptability, flavour, taste, colour. It has been found (Table 5) that only in case of sensory score of flavour, percentage replacement of potato powder does not have significant effect (i.e. $p>0.05,6.38<6.94$ ) on sensory rating of flavour. The comparison in between different sensory attributes like over all acceptability, taste, colour percentage of potato powder that has replaced the wheat flour has a much more influence on sensory rating rather than variation in spices as the larger the $\mathrm{F}$ value denotes the more significance on different attributes of sensory. Hence it can be concluded that in case of sensory rating of flavour, percentage replacement of potato powder following null hypothesis $\left(\mathrm{H}_{0}\right)$ means there is no significant difference on sensory rating for changing in potato powder replacement, the same case has been observed in case of sensory rating of colour, here also deference in spices combination has no significant effect on sensory rating colour means following null hypothesis $\left(\mathrm{H}_{0}\right)$. Without the two cases mentioned above other cases have significant effect on sensory rating separately means following alternating hypothesis $\left(\mathrm{H}_{1}\right)$.

Table 5: Main Effects ANOVA for Cookies Prepared With Different Combination of Potato Powder and Spices

\begin{tabular}{|c|c|c|c|c|c|c|}
\hline \multicolumn{7}{|c|}{ Overall Acceptability } \\
\hline Effect & $\begin{array}{l}\text { SS (Sum of } \\
\text { Square) }\end{array}$ & $\begin{array}{l}\text { Degrees of Freedom } \\
\text { (DF) }\end{array}$ & $\begin{array}{l}\text { MS (Mean of } \\
\text { Square) }\end{array}$ & $\begin{array}{l}\text { F } \\
\text { Value }\end{array}$ & $\operatorname{Prob}^{*}>\mathrm{F}$ & $\begin{array}{l}\text { Standard } \quad F \\
\text { Value }\end{array}$ \\
\hline Variation in Spices & 0.7443 & 2 & 0.3721 & 20.25 & $0.008080 *$ & 6.94 \\
\hline $\begin{array}{l}\% \text { Replacement of } \\
\text { potato powder }\end{array}$ & 2.4001 & 2 & 1.2000 & 65.30 & $0.000883 *$ & 6.94 \\
\hline Error & 0.0735 & 4 & 0.0184 & & & \\
\hline \multicolumn{7}{|l|}{ Flavour } \\
\hline Variation in Spices & 1.4074 & 2 & 0.7037 & 15.58 & $0.012940 *$ & 6.94 \\
\hline $\begin{array}{l}\% \text { Replacement of } \\
\text { potato powder }\end{array}$ & 0.5766 & 2 & 0.2883 & 6.38 & 0.056905 & 6.94 \\
\hline Error & 0.1806 & 4 & 0.0452 & & & \\
\hline \multicolumn{7}{|l|}{ Taste } \\
\hline Variation in Spices & 0.4384 & 2 & 0.2192 & 31.95 & $0.003470^{*}$ & 6.94 \\
\hline $\begin{array}{l}\% \text { Replacement of } \\
\text { potato powder }\end{array}$ & 1.8875 & 2 & 0.9437 & 137.55 & $0.000205^{*}$ & 6.94 \\
\hline Error & 0.0274 & 4 & 0.0069 & & & \\
\hline \multicolumn{7}{|l|}{ Colour } \\
\hline Variation in Spices & 0.0235 & 2 & 0.0117 & 2.1 & 0.236580 & 6.94 \\
\hline $\begin{array}{l}\% \text { Replacement of } \\
\text { potato powder }\end{array}$ & 0.8323 & 2 & 0.4161 & 74.8 & $0.000678^{*}$ & 6.94 \\
\hline Error & 0.0222 & 4 & 0.0056 & & & \\
\hline
\end{tabular}

\section{CONCLUSION}

Among all formulations tried, the cookie samples prepared from $10 \%$ potato powder and $90 \%$ wheat flour as well as from $20 \%$ potato powder and $80 \%$ wheat flour with the optimised combination of cardamom and clove (1:1,1.5:0.5) had the same or higher sensory score than the control. More over the cookies from blended flour had higher percentage of crude fibre and ash (i.e. minerals) than the control cookies. 


\section{REFERENCES}

[1] Artz, W. E., C. C. Warren, A. E. Mohring and R. Villota, (1990), "Incorporation of corn fiber into sugar snap cookies", Cereal Chem. 67:303-305;

[2] Haq, A. U. and M. Shams-ud-Din, (2002), "The effect of aquous extracted wheat bran on the baking quality of cookies", Int. J. Food Sci. Tech. 37:303305

[3] Sudha, M. L., R. Vetrimani and K. Leelawathi, (2007), "Influence of fiber from different cereals on the rheological characteristics of wheat flour dough and on biscuit quality”, Food Chem. 100: 1364-1370

[4] Hylla S, Gostner A, Dusel G, (January 1998). "Effects of resistant starch on the colon in healthy volunteers: possible implications for cancer prevention", Am. J. Clin. Nutr. 67 (1): 136-42

[5] Liu YW, Han CH, Lee MH., Patatin, (2003), "Tuber Storage Protein of Potato (Solanum tuberosum L.), Exhibits Antioxidant Activity in Vitro" J Agric Food Chem. 2003 Jul 16;51(15):4389-93.

[6] Faridi H, Faubion JM, (1986), "Dough rheology: its benefits to cereal chemists", In: Faridi H, Faubion JM(eds) Fundamentals of dough rheology, American Association of Cereal Chemists, Minnesota, pp. 1-9

[7] Noor Aziah, A. A., Mohamad Noor, A. Y. and Ho, L.-H, (2012), International Food Research Journal 19(4): 1539-1543

[8] Laura C. Okpala and Eric C. Okoli. (2011). Advance Journal of Food Science and Technology 3(5): 366375.

[9] Hough, G., Bractchell, N., and Wakeling, I. (1992), "Consumer preference of Dulce de Leche Among Students in the United Kingdom" Journal of Sensory Studies v7: 119-132

[10] Murray, J.M., and Delahunty, C.M., (2000), "Mapping Consumer Preference for the Sensory and Packaging Attributes of Cheddar Cheese", Food Quality and Preference. v11:419-435.

[11] Yeh, J.V., Resurreccion, A.V., Phillips, R.D., and Hung, Y.C., (2002), "Overall Acceptability and Sensory Profiles of Peanut Spreads Fortified with Protein, Vitamins, and Minerals", Journal of Food Science.v67(5):1979-1985

[12] Bantivoglio, K.A. and Tepper, B.J., (1998), "The Use of Trained Sensory Panels in Flavor and Texture Profiling" American Laboratory v30 (6):19-25.

[13] Noronha, R.L., Damasio, M.H., Pivatto, M.M, and Negrillo, B.G., (1995), "Development of the Attributes and Panel Screening for Texture Descriptive Analysis of Milk Gels Aided by Multivariate Statistical Procedures", Food Quality and Preference v6:49-54.

[14] S. Chakraborty, S. Banerjee, and S. Mazumder, (2013), "Statistical optimization of process parameters for gelatinization of potato (Chandramukhi variety)", IJRET, Volume 2, Issue 11, Pages 170-179.

[15] S. Chakraborty, S. Banerjee and S.Mazumder, (2014), "Functional Properties based Statistical Optimization of Foam Mat Drying Parameters for
Potato (Kufri Chandramukhi)", Global Journal of Science Frontier Research: C Biological Science, Volume 14, Issue 2, Pages 1-10.

[16] Peryam, D.R. and Girardot, N.F, (1952), "Advanced taste test method", Food Engineering, 24, 58-61, 194.

[17] AOAC, (1984), Official Methods of Analysis. 14th Edn., Association of Official Analytical Chemists, Washington, DC., USA.

[18] El-sahy KM, Siliha H, (1988), "Use of sulphite treated sweet potato flour in manufacturing of wheat bread", Getreide Mehl und Brot. 42 (7):215-217. 